\title{
SEASONAL FLUCTUATION OF THE LATANIA SCALE INSECT HEMIBERLESIA LATANIAE (SIGNORET) (HOMOPTERA: DIASPIDIDAE) ON FIG TREES IN NEWLEY RECLAIMED AREAS
}

\author{
HASSAN, A. S. ${ }^{1}$, M. M. MANSOUR ${ }^{2}$ AND M. A. EL-DEEB ${ }^{2}$
}

1. Plant Protection Research Inst., ARC, Dokki, Giza

2. Plant Protection Dept., Fac. Agric., Zagazig University

(Manuscript received 22 March 2009)

\begin{abstract}
Field experiments at Sharkia governorate (El-Khattara region) carried out to study the ecology of Hemiberlesia lataniae (Signoret) Homoptera: Diaspididae) on fig trees during two successive seasons 1994 and 1995. Obtained data showed that three peaks were recorded in January, April and November during the two seasons. The highest one was in January for both seasons, with more number in the first season. The main parasitoids on Hemiberlesia lataniae were Aphytis sp. and Aspidiotiphagus sp. Percentage of parasitism during 1994, had two peaks of activity in July and September, while one peak only in June was recorded in 1995. Parasitism was more higher in spring and summer than in autumn and winter. Three overlapping generations were recorded in both seasons, the first, required about three months, the second generation required about seven months, and the third was about two months. The second generation was the weakest one, compared with other generations. Combined effect of temperature and sunny shine had a positive highly significant effect, while R.H. $\%$ and sunny shine showed a negatively significant effect on all stages.
\end{abstract}

\section{INTRODUCTION}

Fig trees, (Ficus carica) is considered one of the most important fruit crop in newly reclaimed areas. A lot of efforts and attempts were done to obtain crop with high quality which will be acceptable for the foreign export market. According to the journal of Agriculture Economic (Minstry of Agriculture), 1986 and 1996, the total cultivated area of fig trees in Egypt has been rapidly increased and reached to about 3624 feddans producing a yield of approximately 10032 tons fig fruits. These areas increased during few year and reached about 63554 fiddans in (1996) producing a yield of approximately 202697 tons.

Latania scale insect, $H$. lataniae is usually considered as the most important pest of fig trees. The super family Coccoidea includes the greatest numbers of insect species, which attack this crop, causing serious damage, distortion of foliage, fruit, blossoms, tummer formation and reduction in the general plant vigors. Moreover, physiological disturbances are expected to occur, such as plasmolysis, secretional, honeydew which provides a suitable media for the growth of sooty mould. 
Hall, (1923 and 1924), Brimblecombe, (1968) noticed the crawlers of $H$. lataniae during March to April and from July to August on infested fruit trees in Alexandria. Also, they added that females increased during summer months towards a peak occurred at the beginning of August. El- Minshawy et al., (1972) stated that Hemiberlesia latania (sign) has three generations a year when reared in laboratory on Pumpkin, the crawlers being present in September- October, March- April and JulyAugust, reproduction was parthenogenic. He added that Hemiberlesia lataniae (sign.) had two generations a year in the field, reached maximum abundance in September. Salama and Hamdy, (1974) recorded that the crawlers of this insect were found during March to April and from July to August on infested fruit trees in Alexandriawhile adult females increased in summer months towards a peak existing at the beginning of August.

Fawzia, Hassanin and Hamed (1985) mentioned that Hemiberlesia lataniae has four peaks on Ficus nitida trees throughout the year, which occurred at the second week from each, April, Jun and December and the first week of August. Mean temperature, was $20.3 \mathrm{C}^{\circ}, 28.5 \mathrm{C}^{\circ}$ and $14.5 \mathrm{C}^{\circ}$ during these periods, respectively. Medina - Gaud et al, - (1987) in Puerto Rico reported that the coccids Astendecanium pustuians (ckll.) and the Diaspidides. Hemiberlesia Latania (Sign.) were collected from heavily infested twiges and leaves of Nispero. Mansour et al (1991) noticed that the population dynamics of $H$. Lataniae and its parasite in Sharkia Govemorate during two seasons (1987-1988). The population density in the first year was higher with about two times more than that in the second year, and it has 2-8 times more in the inner zone of trees (guava trees) than in the peripheral one.

The aim of the present work is to study the occurrence and seasonal fluctuation of all stages and its associated parasitoids on fig trees in newly reclaimed areas.

\section{MATERIALS AND METHODS}

The present work was carried out at El-Khattara region, El-Sharkia Governorate, during two successive years, (1994 and 1995).

Five fig trees of similar size, age and vegetation were chosen to study this insect fluctuations. Samples of 12 terminal branches cuttings $30 \mathrm{~cm}$ long diameter 0.8 $\mathrm{cm}$ each for every tree.

Sample size was 60 cuttings representing 5 trees 12 terminal cutting branch. These samples were chosen randomly from different heights and directions and kept in polyethelene bags, then samples were transferred into the laboratory and examined by the aid of sterio-microscope bionocular. Alive and dead stages of $H$. Lataniae and 
its parasitoids were recorded. Recorded weather factors prevailing during the experiment period were obtained from the meterorological station, also light intensity measured by luxmetr in the field when the sun was perpendicular on the earth 12 a.m.

Obtained data were statistically analyzed by using simple correlation and partial regression (Fisher 1950).

\section{RESULTS AND DISCUSSION}

\section{Hemiberlesia lataniae (Signoret)}

Hemiberlesia lataniae is considered as one of the most important armored scale insect infesting fig trees in Egypt. The seasonal fluctuation of different stages and peaks of activity for each stage and its parasites were also counted and recorded.

\section{Female population:}

During the first season 1994, data given in (Table 1) indicated that females of $H$. Lataniae had three peaks of activity in January (6601), April (5500) and November (871 female). On the other hand, in the second season 1995 peaks only two were recorded in February (2248 female) and November (1211 female). The total number of $H$. Lataniae females were higher in the first season in comparison with the second one with approximately ratio of $3: 1$.

\section{Nymphs population,}

Population density of nymphs (Tables $1 \& 2$ ), indicated that there were three peaks of activity for both season, 1994 and 1995, in January (12958 \& 14258 nymphs), April (7283 \& 4216 nymphs) and November (10337 \& 15147 nymphs). On the other hand, the total number of nymphs in the first season, 1994 was higher than in the second one.

\section{Total alive stages:}

Data tabulated in (Tables 1\&2) showed that the total alive stages of $H$. Lataniae on Fig trees has the same behaviour in which three peaks in January (19509 \& 15292 scales), April (12783 \& 4646 scales) and November (11208 \& 16358 scales) during the two seasons 1994 \& 1995 were found. The highest one was recorded in January for both seasons. According to the total numbers of insects, it could be noticed that the infestation during the first season was higher than that in the second one, which numbers were recorded ( 72402 scales) (53624 scales) in the first and second season, respectively.

The above maintained results were in agreement with the studies by Shahein et al., (1987), recorded that two periods of abundance with three peaks on Guava, the 
first peak in June, the second and highest in October and the third in December. Mansour et al., (1991), stated that $H$. Lataniae has three peaks of infestation on Guava trees during two seasons 1987 \& 1988. The main period of activity occurred during winter and early spring in the first season and during the whole period of the second season except in summer months.

\section{Total of non alive insects and Percentage of total mortality:}

Two peaks of total non alive insects were recorded during the first season 1994 in January (3095 individual) and April (5906 individual), where the highest one occurred in April (5906 individual), while in the second season 1995, four peaks of dead insects were recorded in January (6514 individual), March (5794 individual), July (1507 individual) and November (885 individual). On the other hand the total numbers of non alive insects in the first season 1994 was higher than in the second one (Tables, 1 and 2).

Also, four peaks of total percentage mortality during the first season, 1994 were recorded in January (13.7\%), March (40\%), June (72.3\%) and September (34.5\%), while in the second season 1995 three peaks were recorded in January (29.9\%), March (70.5\%) and July (85.6\%).

\section{Percentage of parasitism:}

Data given in (Tables, 1\&2), cleared that in the first season, 1994, two peaks of activity were recorded in July (10.7\%) and September (9.9\%). While in the second season, 1995 only one weak peak was recorded in June (3.8\%).

On the other hand, considering parasitism percentage during the four seasons (spring, summer, autumn and winter) it could be noticed that in both season parasitism was higher in spring and summer in comparison with autumn and winter. Also, parasitism percentage during the first season was higher than in the second one. These results were in agreement with the studies by Taraboulsi, (1969), in Lebanon recorded, Aphytis maculicornis on H. Lataniae. Mansour et al., (1991), who mentioned that Aphytis sp was found as effective parasite on $H$. Lataniae, with 2-3 peaks of parasitism during the two seasons

\section{Effect of climatic factors:}

* On Female: Results obtained in (Tables, 3\&4) indicated that in the first season, 1994 both temperature and sunny shine had a negatively significant effects $(r<=$ $-0.6287 * \&-0.6091 *$ ), while in the second season, 1995 , a negatively highly significant effect for these factors $\left(r=-0.8287^{* *}\right.$ and $\left.-0.7213^{* *}\right)$ were found.

* On Nymphs: Data given in (Table, 3) showed that in the first season 1994 both of temperature and sunny shine have a negatively highly significant effects on nymphs where, ( $r=-0.8191^{* *}$ and $\left.-0.8624^{* *}\right)$, Table (3), while light intensity 
has less significantly effect, where $\left(r=-0.6648^{*}\right)$.

In the second season 1995 sunny shine and temperature had a negatively significant effect on nymphs $r=-0.7292 * *$ and $-0.6375 *$, respectively (Table 4).

* On total alive stages: Data given in Tables ( $3 \& 4$ ), indicated that in, a negatively highly significant effect for both temperature and sunny shine were recorded in the first season 1994 where $r=-0.7965 * * \&-0.8194 * *$, respectively, also light intensity had a less negatively significant effect where $r=-0.6251 *$.

In the second season 1995 sunny shine had a negatively highly significant effect on total alive insects $(r=-0.7780 * *)$, while temperature had less negatively significant influence $\left(r=-0.6988^{*}\right)$.

* On Total of non alive and on mortality \%: Data given in (Tables, 3\&4) indicated that there is no significant effect for the tested climatic factors on non alive insects during the two seasons.

However sunny shine had positively significant effect on percentage of mortality in both seasons $\left(r=-0.7168^{*} \&-0.7526 * *\right)$, respctively.

* Percentage of parasitism: Data given in Table (3) showed, that in the first season 1994, temperature and sunny shine had a positively highly significant effect on percentage of parasitism where ( $r=-0.7564 * *$ and $\left.0.6473^{*}\right)$ for both factors, respectively. On the other hand in the second season 1995, R.H \% had a negatively highly significant effect on percentage of parasitism $\left(r=-0.8456^{* *}\right)$, while sunny shine had a positively significant effect, where $(r=0.6611 *)$.

\section{Combined effect of climatic factors:}

The statistical analysis of the combined effect of all tested climatic factors on all previously mentioned aspects was giving in (Tables 3\&4). In the first season 1994 it was clearly noticed that the combined effect between temperature and both of sunny shine and light intensity had a highly positively significant effect where $(r=0.8123 * *$ and $0.7488^{* *}$ ), respectively, while R.H \% in relation with the same factors had a negatively significantly effect where $\left(r=-0.5866^{*}\right.$ and-0.7451**) for both factors respectively. A positively highly significantly effect was obtained between sunny shine and light intensity, $\left(r=0.7555^{*}\right)$.

In the second season, 1995 the combined effect between all tested climatic factors was less than in the first one. Temperature effect was a positively highly significantly with sunny shine, where $\left(r=0.9115^{* *}\right)$, while R.H\% had a negatively significantly effect with sunny shine $\left(r=-0.6299^{*}\right)$. 
Generally in both seasons the combined effect between temperature and sunny shine indicated that a positively highly significantly effect on all stages, while between $\mathrm{RH} \%$ and sunny shine had a negatively significantly effect.

These results were in agreement with, the studies of Mansour et al., (1991), who mentioned that the effect of abiotic factors showed that there was a strongly correlated between temperature and both of insect population and its parasites, and the combined effect between temperature and peripheral light intensity during both seasons, which showed positive highly significant effects, and between R.H \% and inner light intensity, revealing a negative significantly effect. Negative significantly combined effects were also recorded between temperature and R.H \%.

\section{Number of generations}

Results in tabulated (Table 5) and (Fig 3) indicated three overlapping generations for both seasons, 1994 and 1995 by using method of Audemerd and Millairel, (1975), and emended by Jacob (1977). The first generation took about three months in both season, from the beginning of January till the end March. The second lasted about seven months in both seasons, beginning of April till the end of October. The third for both season, 1994 and 1995 took about two months from the beginning of October till the end of December.

Generally three overlapping generations were recorded in both seasons. The first and the third overlapping generations for both seasons 1994 and 1995 was the highest one, while the second generation was the weakest one, for both generations as it lasted for about 7 months.

These results were in agreement with Mansour et al, (1991) who mentioned that $H$. Lataniae had three generations on Guava trees in Sharkia Governorate. On the other hand, EL- Minshawy et al (1912Y recorded two only generations for $H$. Lataniae in field. Fawzia Hassanien and Hamed, (1985) found four peaks for $H$. Lataniae on Ficus nitida trees. 


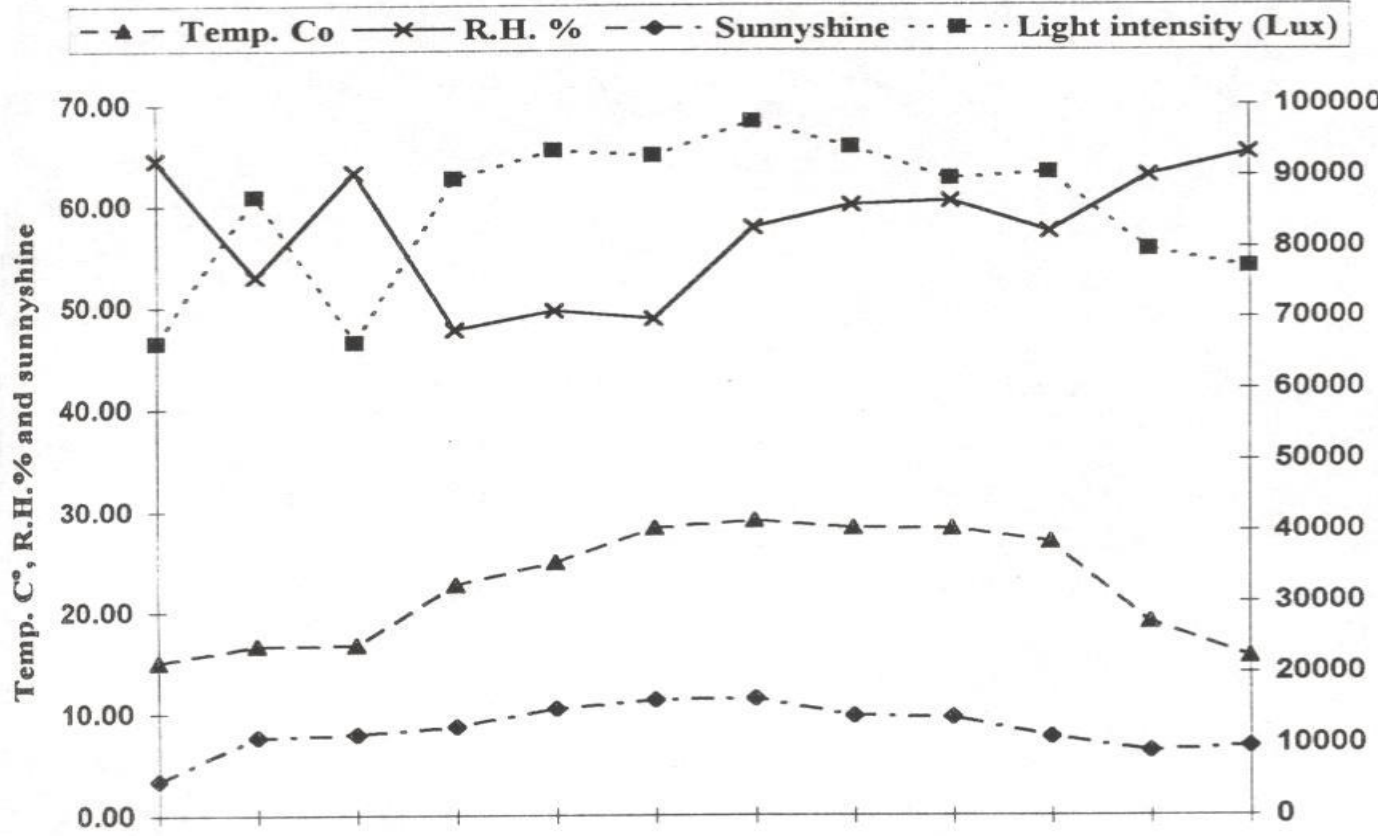

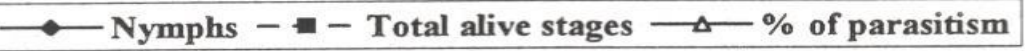

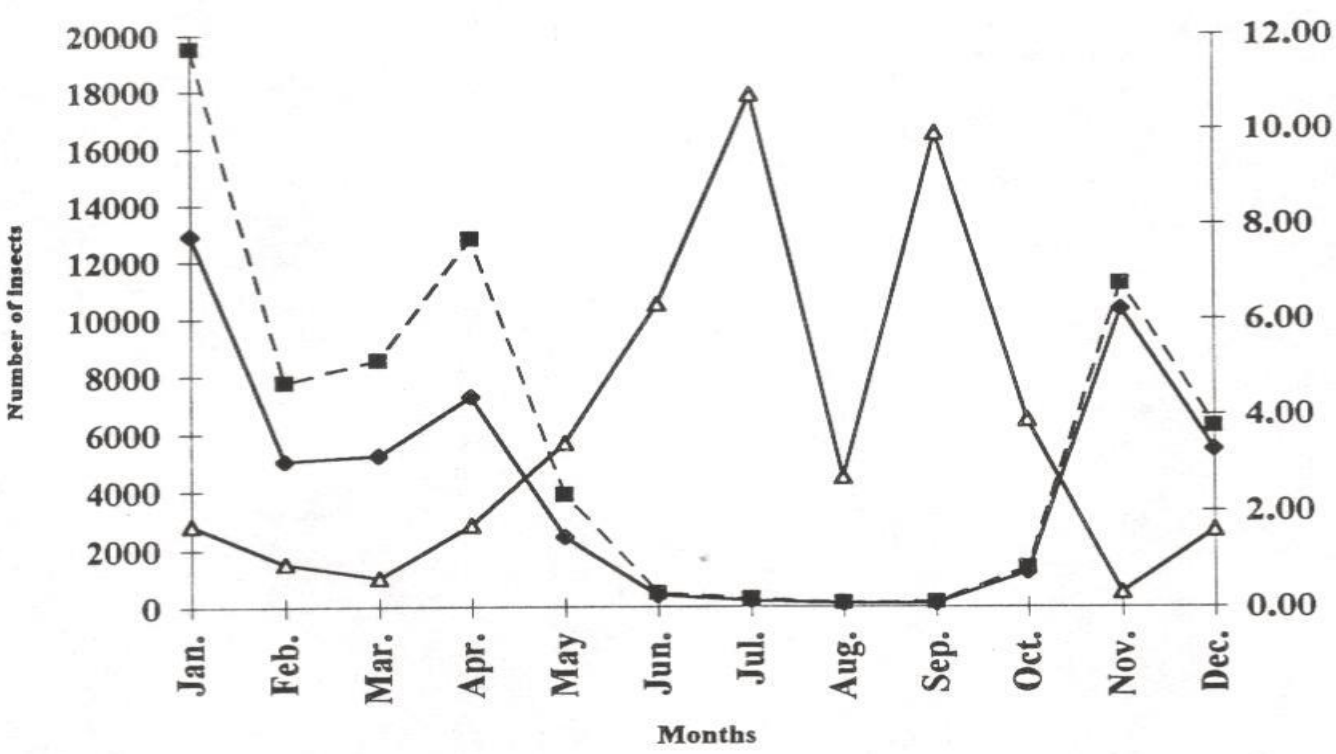

ह

Fig. 1. Seasonal abundance of $H$. lataniae and percentage of parasitism on fig trees during the first season 1994. 

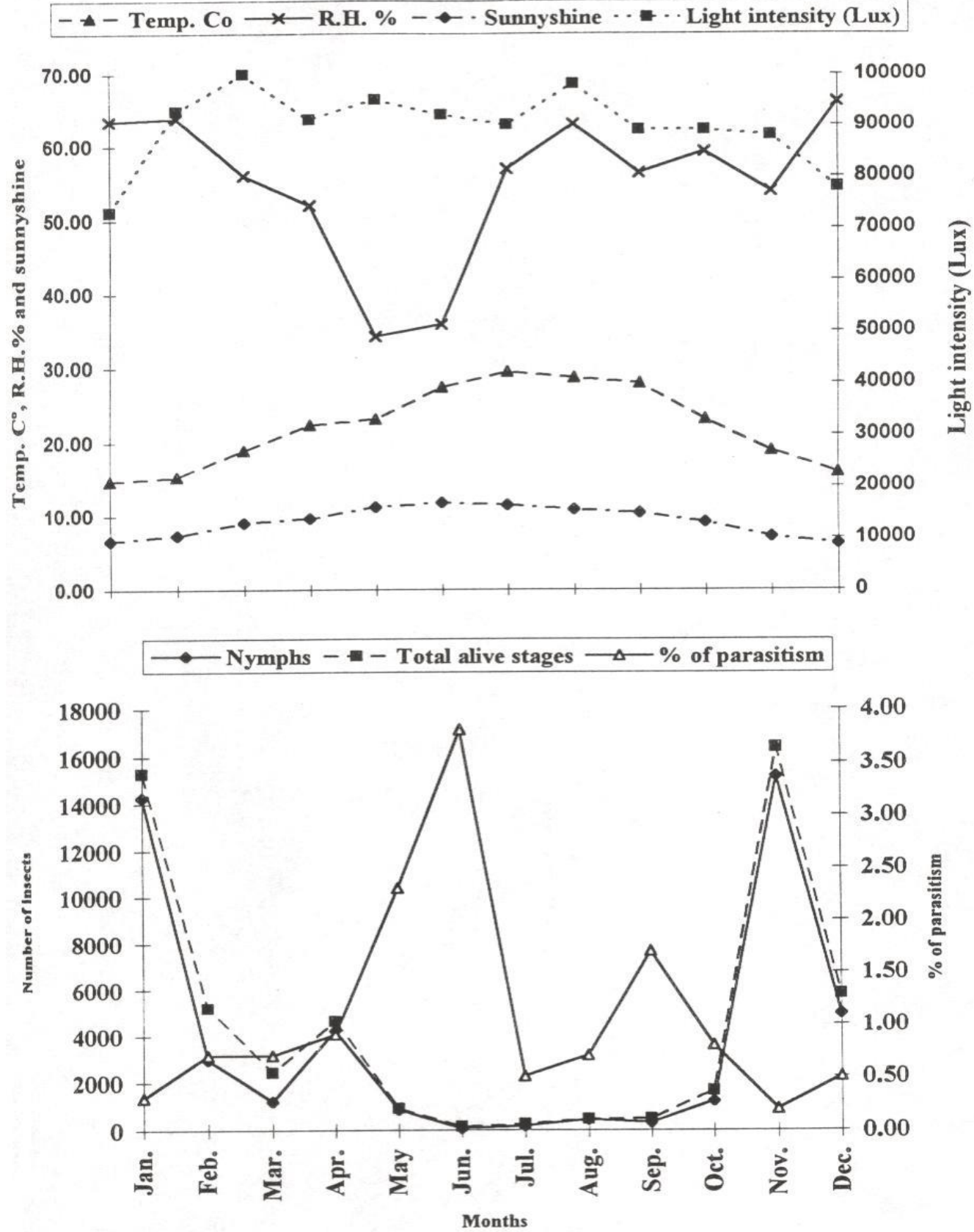

Fig. 2. Seasonal abundance of $H$. lataniae and percentage of parasitism on fig trees during the second season 1995. 
1994

G3

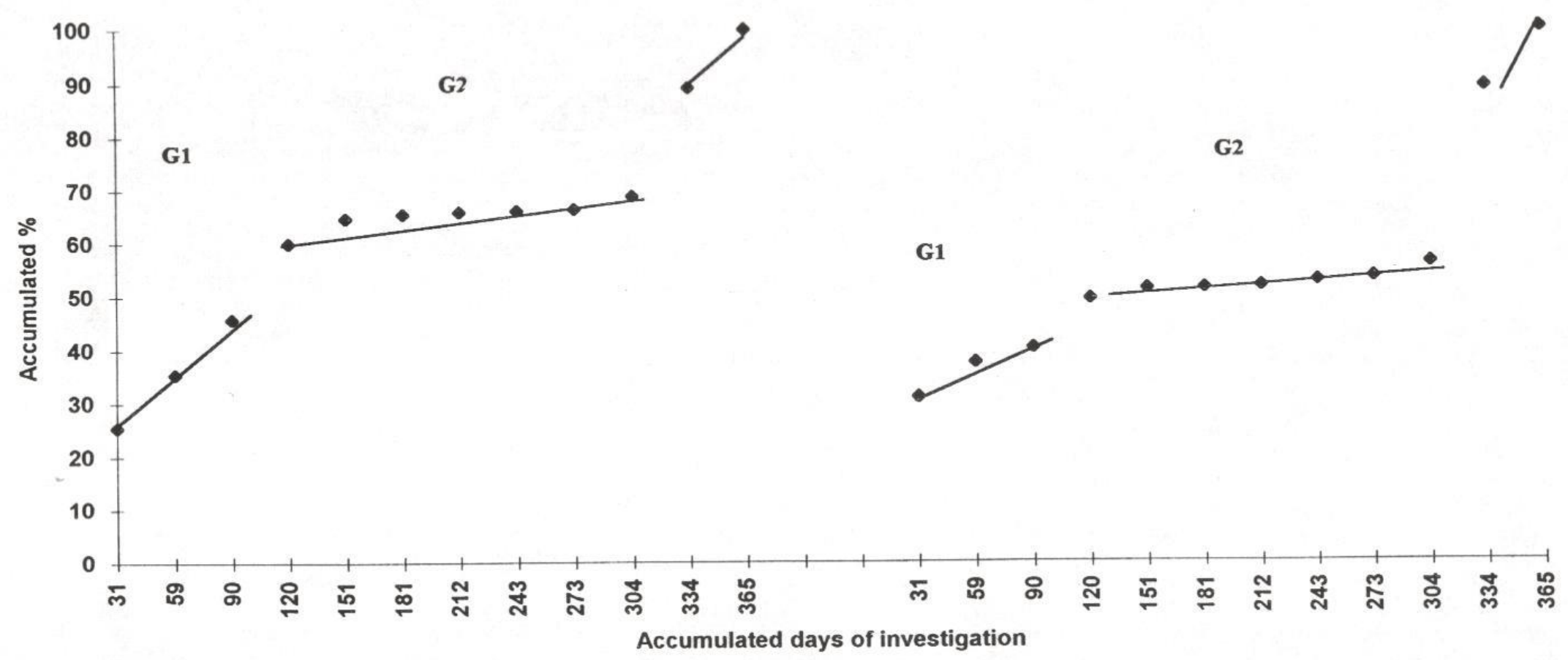

Fig. 3. Annual generations and duration of Hemibelasia Lantaniure latcmiae under field condition on fig trees during the two seasons1994 and 1995. 
Table 1. Seasonal abundance of Hemiberlesiae lataniae on fig trees in El-Khattara region, Sharkia Governorate during the first season 1994.

\begin{tabular}{|c|c|c|c|c|c|c|c|c|c|c|}
\hline \multirow{3}{*}{ Months } & \multicolumn{6}{|c|}{ Number of insects/60 twigs } & \multicolumn{4}{|c|}{ Monthly average of climatic factors } \\
\hline & \multicolumn{3}{|c|}{ Alive } & \multirow{2}{*}{$\begin{array}{c}\text { Total of } \\
\text { non alive } \\
\text { insects }\end{array}$} & \multirow{2}{*}{$\begin{array}{c}\text { Mortality } \\
\text { (\%) }\end{array}$} & \multirow{2}{*}{$\begin{array}{c}\text { Parasitism } \\
\text { (\%) }\end{array}$} & \multirow{2}{*}{$\begin{array}{c}\text { Temp. } \\
\left({ }^{\circ} \mathrm{C}\right)\end{array}$} & \multirow[b]{2}{*}{ R.H. (\%) } & \multirow{2}{*}{$\begin{array}{l}\text { Sunny } \\
\text { shine } \\
\text { (hr.) }\end{array}$} & \multirow{2}{*}{$\begin{array}{c}\text { Light } \\
\text { intensity } \\
\text { (Lux) }\end{array}$} \\
\hline & Females & Nymphs & Total & & & & & & & \\
\hline Jan. & 6601 & 12908 & 19509 & 3095 & 13.7 & 1.7 & 15.0 & 64.5 & 3.4 & 66400 \\
\hline Feb. & 2715 & 5058 & 7773 & 1178 & 13.2 & 0.9 & 16.6 & 53.0 & 7.6 & 78000 \\
\hline Mar. & 3292 & 5243 & 8535 & 5680 & 40.0 & 0.6 & 16.7 & 63.3 & 7.9 & 66400 \\
\hline Apr. & 5500 & 7283 & 12783 & 5906 & 31.6 & 1.7 & 22.7 & 47.7 & 8.7 & 89600 \\
\hline May & 1452 & 2443 & 3895 & 3456 & 47.0 & 3.4 & 24.9 & 49.6 & 10.4 & 93600 \\
\hline Jun. & 107 & 387 & 494 & 1288 & 72.3 & 6.3 & 28.3 & 48.8 & 11.3 & 92800 \\
\hline Jul. & 61 & 214 & 275 & 168 & 37.9 & 10.7 & 29.0 & 57.9 & 11.4 & 97600 \\
\hline Aug. & 31 & 107 & 138 & 55 & 28.5 & 2.7 & 28.3 & 60.1 & 9.7 & 94000 \\
\hline Sep. & 37 & 126 & 163 & 86 & 34.5 & 9.9 & 28.2 & 60.5 & 9.6 & 89600 \\
\hline Oct. & 154 & 1208 & 1362 & 182 & 11.8 & 3.9 & 26.9 & 57.5 & 7.7 & 90400 \\
\hline Nov. & 871 & 10337 & 11208 & 782 & 6.5 & 0.3 & 19.0 & 63.0 & 6.3 & 79600 \\
\hline Dec. & 798 & 5469 & 6267 & 1454 & 18.8 & 1.6 & 15.6 & 65.3 & 6.8 & 77200 \\
\hline Total & 21619 & 50783 & 72402 & 23330 & 24.4 & 3.6 & & & & \\
\hline
\end{tabular}


Table 2. Seasonal abundance of Hemiberlesiae lataniae on fig trees in El-Khattara region, Sharkia Governorate during the second season, 1995.

\begin{tabular}{|c|c|c|c|c|c|c|c|c|c|c|}
\hline \multirow{3}{*}{ Months } & \multicolumn{6}{|c|}{ Number of insects/60 twigs } & \multicolumn{4}{|c|}{ Monthly average of climatic factors } \\
\hline & \multicolumn{3}{|c|}{ Alive } & \multirow{2}{*}{$\begin{array}{c}\text { Total of } \\
\text { non alive } \\
\text { insects }\end{array}$} & \multirow{2}{*}{$\begin{array}{c}\text { Mortality } \\
(\%)\end{array}$} & \multirow{2}{*}{$\begin{array}{c}\text { Parasitism } \\
\text { (\%) }\end{array}$} & \multirow{2}{*}{$\begin{array}{l}\text { Temp. } \\
\left({ }^{\circ} \mathrm{C}\right)\end{array}$} & \multirow[b]{2}{*}{ R.H. (\%) } & \multirow{2}{*}{$\begin{array}{c}\text { Sunny } \\
\text { shine } \\
\text { (hr.) }\end{array}$} & \multirow{2}{*}{$\begin{array}{c}\text { Light } \\
\text { intensity } \\
\text { (Lux) }\end{array}$} \\
\hline & Females & Nymphs & Total & & & & & & & \\
\hline Jan. & 1034 & 14258 & 15292 & 6514 & 29.9 & 0.3 & 14.7 & 63.4 & 6.6 & 73000 \\
\hline Feb. & 2248 & 2954 & 5202 & 1376 & 20.9 & 0.7 & 15.3 & 63.8 & 7.3 & 92.667 \\
\hline Mar. & 1222 & 1200 & 2422 & 5794 & 70.5 & 0.7 & 18.9 & 56.0 & 9.0 & 100000 \\
\hline Apr. & 430 & 4216 & 4646 & 1304 & 21.9 & 0.9 & 22.3 & 52.0 & 9.6 & 91000 \\
\hline May & 54 & 852 & 906 & 552 & 37.9 & 2.3 & 23.1 & 34.2 & 11.1 & 95000 \\
\hline Jun. & 82 & 62 & 144 & 222 & 60.7 & 3.8 & 27.3 & 35.8 & 11.7 & 92000 \\
\hline Jul. & 83 & 171 & 254 & 1507 & 85.6 & 0.5 & 29.4 & 56.9 & 11.4 & 90000 \\
\hline Aug. & 25 & 436 & 461 & 1196 & 72.2 & 0.7 & 28.6 & 63.1 & 10.8 & 98000 \\
\hline Sep. & 179 & 302 & 481 & 407 & 45.8 & 1.7 & 27.9 & 56.4 & 10.3 & 89000 \\
\hline Oct. & 424 & 1229 & 1653 & 179 & 9.8 & 0.8 & 23.1 & 59.3 & 9.1 & 89000 \\
\hline Nov. & 1211 & 15147 & 16358 & 885 & 5.1 & 0.2 & 18.8 & 54.0 & 7.1 & 88000 \\
\hline Dec. & 853 & 4952 & 5805 & 405 & 6.5 & 0.5 & 15.9 & 66.2 & 6.2 & 78000 \\
\hline Total & 7845 & 45779 & 53624 & 20341 & 27.5 & 1.1 & & & & \\
\hline
\end{tabular}


Table 3. Statistical analysis based on correlation coefficient ( $r$ ) indicated the effect of climatic factors on different stages of $H$. lataniae on fig trees in El-Khattra region, Sharkia Governorate during First season 1994 season.

\begin{tabular}{|c|c|c|c|c|c|c|c|c|}
\hline & \multirow[b]{2}{*}{ Temp. ( $\left.{ }^{\circ} \mathrm{C}\right)$} & \multirow[b]{2}{*}{ R.H. (\%) } & \multirow[b]{2}{*}{ Sunny shine (hr. } & \multirow{2}{*}{$\begin{array}{c}\text { Light } \\
\text { intensity (Lux) }\end{array}$} & \multicolumn{4}{|c|}{ Combined effect } \\
\hline & & & & & & $\begin{array}{l}\text { R.H. } \\
(\%)\end{array}$ & $\begin{array}{c}\text { Sunny } \\
\text { Shine (hr.) }\end{array}$ & $\begin{array}{c}\text { Light } \\
\text { intensity (Lux) }\end{array}$ \\
\hline Female & $-0.6283^{*}$ & -0.0261 & $-0.6091^{*}$ & -0.4632 & Temp. $\left({ }^{\circ} \mathrm{C}\right)$ & -0.4287 & $0.8123 * *$ & $0.7488 * *$ \\
\hline Nymphs & $-0.8191 * *$ & 0.3308 & $-0.8624 * *$ & $-0.6648 *$ & R.H. (\%) & & $-0.5866 * *$ & $-0.7451 * *$ \\
\hline Total number of alive & $-0.7965 * *$ & 0.2192 & $-0.8194 * *$ & $-0.6251^{*}$ & Sunny shine & & & $0.7555 * *$ \\
\hline Total of non alive insects & -0.4454 & -0.2254 & -0.1921 & -0.1808 & & & & \\
\hline$\%$ of total mortality & 0.5159 & -0.5389 & $0.7526 * *$ & 0.3501 & & & & \\
\hline$\%$ of parasitism & $0.7564 * *$ & -0.1471 & $0.6473 *$ & 0.3562 & & & & \\
\hline
\end{tabular}

Table 4. Statistical analysis based on correlation coefficient ( $r$ ) indicated the effect of climatic factors on different stages of $H$. lataniae on fig trees in El-Khattra region, Sharkia Governorate during second season 1995 season.

\begin{tabular}{|c|c|c|c|c|c|c|c|c|}
\hline & \multirow[b]{2}{*}{ Temp. $\left({ }^{\circ} \mathrm{C}\right)$} & \multirow[b]{2}{*}{ R.H. (\%) } & \multirow[b]{2}{*}{ Sunny shine (hr. } & \multirow{2}{*}{$\begin{array}{c}\text { Light } \\
\text { intensity (Lux) }\end{array}$} & \multicolumn{4}{|c|}{ Combined effect } \\
\hline & & & & & & $\begin{array}{l}\text { R.H. } \\
(\%)\end{array}$ & $\begin{array}{c}\text { Sunny } \\
\text { Shine (hr.) }\end{array}$ & $\begin{array}{c}\text { Light } \\
\text { intensity (Lux) }\end{array}$ \\
\hline Female & $-0.8287 * *$ & 0.4621 & $-0.7213 * *$ & -0.2979 & Temp. $\left({ }^{\circ} \mathrm{C}\right)$ & -0.3816 & $0.9115^{* *}$ & 0.3171 \\
\hline Nymphs & $-0.6375^{*}$ & 0.2655 & $-0.7292 * *$ & -0.1465 & R.H. (\%) & & $-0.6299 *$ & -0.2323 \\
\hline Total number of alive & $-0.6988 *$ & 0.3051 & $-0.7780 * *$ & -0.1735 & Sunny shine & & & 0.2802 \\
\hline Total of non alive insects & -0.4612 & 0.3689 & -0.3388 & -0.4339 & & & & \\
\hline$\%$ of total mortality & -0.2778 & 0.1606 & $0.7168^{*}$ & 0.2501 & & & & \\
\hline$\%$ of parasitism & -0.0498 & $-0.8456 * *$ & $0.6611^{*}$ & 0.1313 & & & & \\
\hline
\end{tabular}


Table 5. Number of generations and duration of $H$. lataniae on fig trees in El-Khattara region, Sharkia Governorate during the seasons, first and second 1994 and 1995.

\begin{tabular}{|c|c|c|c|c|c|c|c|}
\hline \multirow[b]{2}{*}{ Months } & \multirow[b]{2}{*}{$\begin{array}{c}\text { Accumulated } \\
\text { days of } \\
\text { investigation }\end{array}$} & \multicolumn{3}{|c|}{1994} & \multicolumn{3}{|c|}{1995} \\
\hline & & $\begin{array}{l}\text { Monthly } \\
\text { counts of } \\
\text { nymphs }\end{array}$ & $\begin{array}{l}\text { Accumulated } \\
\text { monthly counts }\end{array}$ & $\begin{array}{c}\text { Accumulative } \\
(\%)\end{array}$ & $\begin{array}{l}\text { Monthly } \\
\text { counts of } \\
\text { nymphs }\end{array}$ & $\begin{array}{l}\text { Accumulated } \\
\text { monthly counts }\end{array}$ & $\begin{array}{c}\text { Accumulative } \\
(\%)\end{array}$ \\
\hline Jan. & 31 & 12908 & 12908 & 25.42 & 14258 & 14258 & 31.15 \\
\hline Feb. & 59 & 5058 & 17966 & 35.38 & 2954 & 17212 & 37.60 \\
\hline Mar. & 90 & 5243 & 23209 & 45.71 & 1200 & 18412 & 40.22 \\
\hline Apr. & 120 & 7283 & 30492 & 60.04 & 4216 & 22628 & 49.43 \\
\hline May & 151 & 2443 & 32935 & 64.86 & 852 & 23480 & 51.29 \\
\hline Jun. & 181 & 387 & 33322 & 65.62 & 62 & 23542 & 51.42 \\
\hline Jul. & 212 & 214 & 33563 & 66.04 & 171 & 23713 & 51.80 \\
\hline Aug. & 243 & 107 & 33643 & 66.25 & 436 & 24149 & 52.75 \\
\hline Sep. & 273 & 126 & 33769 & 66.50 & 302 & 24451 & 53.41 \\
\hline Oct. & 304 & 1208 & 34977 & 68.88 & 1229 & 25680 & 56.10 \\
\hline Nov. & 334 & 10337 & 45314 & 89.23 & 14147 & 40827 & 89.18 \\
\hline Dec. & 365 & 5469 & 50783 & 100 & 4952 & 45779 & 100 \\
\hline
\end{tabular}




\section{REFERENCES}

1. Audemard, H. and H. G., Milaire. 1975. Le pieeage carpocapse (Laspeyresia pomonella L.) avec une pheromone sexuelle de synthese: premiers resultats utilisables pour 1 estimation des populations et laconduite de la lutte. Ann. Zool. Ecol. anim: 7-61.

2. EL-Minshawy, A. M., S.K. EL-Sawaf and A. Donia. 1972a. The biololgy of Hemiberlesia latania (sig.) in Alexandria district. Bull. Ent. Soc, Egypt, 56: 461 467.

3. EL-Minshawy, A. M., S.K. EL- Sawaf, S.M. Hammad, and A. Donia. 1972b. The biology of Asterolecanium pustulans Ckll, in Alexandria District, (Hemi-Hom: Asterolecanidae). Bulletin de La Societe Entomologique d' Egypt. 55: 441-446.

4. Fawzia A. Hassanien and A. R. Hamed. 1985. On the population dynamics of Hemiberlesia lataniae Signoret and its parasite, Habrolepis aspidioti Compare \& Annecke in Egypt, Bull. Ent. Soc, Egypt, Econ,. Ser., 14: 63 - 72.

5. Fisher, A.R. 1950. Statistical methods for research worker. (Oliver and Boyd, Edin burgh and London).

6. Hall, W.J. 1923. Further observations on the Coccidae of Egypt. Minist. of Agric. Tech. and Sci. Service, 36: 39 - 52. 1924. The insect pests of citrus trees in Egypt. Minist. of Agric. Tech. and Sci. Service 45: 210.

8. Jacob, N. 1977. un model matematic pentru stabilirea Limitelor economice de toloranta a atacului molilor Fructelor in Iupte integrata. Analele I. C. P. P. 15: 179 Romania.

9. Mansour, M. M., A. Shahein, M. A. EL-Deeb and A. S. Hassan. 1991. Population dynamics and seasonal abundance of Hemiberlesia lataniae (Signoret) and its parasites on Guava trees in Sharkia region, Egypt. J. Appl. Sci. 96 (7) 323 -335.

10. Medina - Guad, S., F. G. Covas, E. Abreu and R. Ingles. 1987. The insects of Nespero (Manilkora Zopota (L.) P. (van Rogen) in Peurto Rico. Journal of Agric. of the Univ. of Peurto Rico 71: 129-132.

11. Salama H. S. and M. K. Hamdy. 1974. Studies on the population of two scale insects infesting Fig trees in Egypt. Zeitschrift fur Angewandte Entomologie, 2: 200 - 204.

12. Shahein A., M. A. EL-Deeb and Z. A. Mohamed. 1987. Abundance of two Coccidae \& Diaspidid Species Kilifa acuminata and Hemiberlesia latania on three fruit crops 2nd Nat. Conf. of pests and Dis. of veg. and Fruits Ismailia, October, 1987, PP: 570 - 576.

13. Taraboulsi, R. 1969. Contribution a L" etude des Aphytis howard Liban (Hym.: Chalcidoidea, Aphelinidae). Annls. Soc. Ent. Fr. N5, 1: 5 - 72. 
التقلبات الموسمية لحشرة اللاتانيا القشرية على أشجار التين فى المناطق المستصلحة حديثا

$$
\begin{aligned}
& \text { عبد المنعم شوقي حسن' ، منصور محمد منصور' ، محمد على الايب' } \\
& 1 \text { - معه بحوث وقاية النباتات - مركز البحوث الزراعية - جيزة } \\
& \text { r- قسم وقاية النبات - كلبة الزراعة - جامعة الزقازيق }
\end{aligned}
$$

أجريت التجارب بمزرعة كلية الزراعة - جامعة الزقازيق بمنطقة الخطارة محافظة الثـرقية

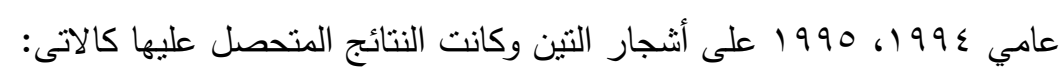

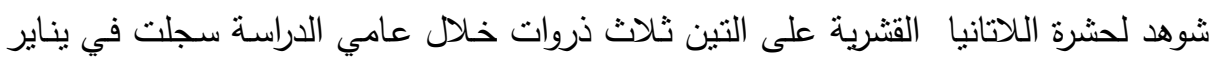

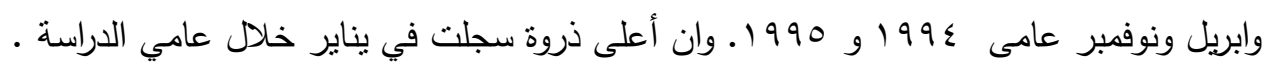

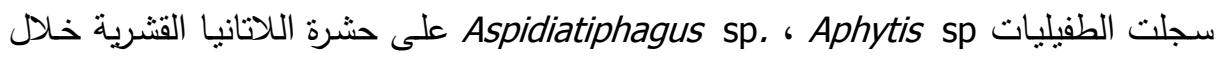

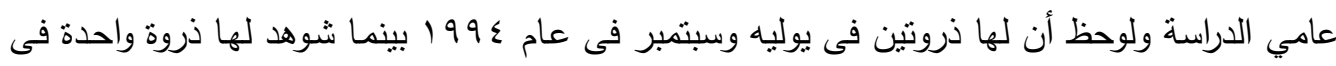

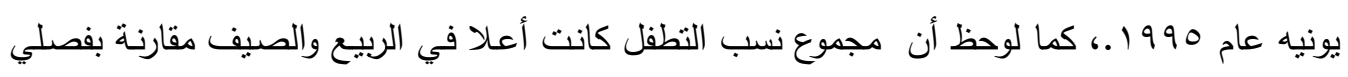

$$
\text { الخريف والشتاء خلال عامي الدراسة. }
$$

سجل للحشرة ثلاث أجيال خلال عامي الدراسة 990 199 199 الجيل الأول مدته ثلاث شهور

$$
\text { والثاني سبعة شهور بينما اخذ الجيل الثالث شهرين وان الجيل الثاني كان الأضعف. }
$$

كذلك وجد ارتباط معنوي موجب بين كل من درجات الحرارة وعدد ساعات النهار بينما كان

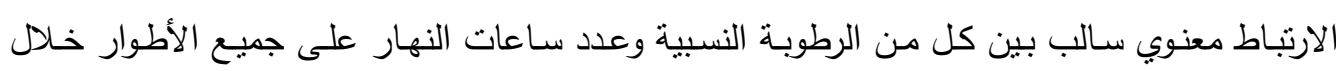
عامي الدراسة. 